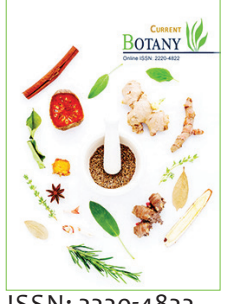

ISSN: $2220-4822$
Received: 21-05-2020 Revised: $23-12-2020$ Accepted: $24-12-2020$ Published: 29-12-2020

*Corresponding Author: Arun R. Pillai

Email: arun4apl@gmail.com

\section{A review on the unexplored and underutilized Arenga species in India}

\author{
Arun R. Pillai", C. T. Riyas', K. K. Sabu²

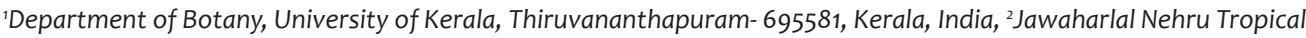 \\ Botanic Garden and Research Institute, Palode, Trivandrum-695562, Kerala, India
}

\begin{abstract}
The Genus Arenga which includes some of the magnificent palms of the world, their multipurpose utility and diversity is been reviewed to shed light on the wide potentialities of the different species. Of the 24 species reported only few of them has been recognized as candidates for domestication from the wild. Four species namely Arenga pinnata, A. obtusifolia, A. micranta and A. wightii have been reported from India. Their ecological aspects, utilization and conservation strategies of the tribal communities have been discussed. Seed biology of few species has been reviewed along with the available data generated through scientific studies. Although most of the members in this Genus have the potential to be explored commercially, they still fall into the underutilized category. The review is mainly intended to highlight the untapped resources from different species in this Genus which will promote more scientific studies and result in proper conservation and sustainable utilization of these valuable palms.
\end{abstract}

Keywords: Arenga, underutilized, tropical palms, palm toddy, tribal community

\section{INTRODUCTION}

The family Arecaceace, also known as Palmae, includes six subfamilies, about 200 genera, and the species count ranges from 2500-2700 [1]. Their geographic distribution between $44^{\circ}$ North and $44^{\circ}$ South indicates that they mostly prefer tropical ecosystems [2]. The highest palm diversity is reported to be in Asia and the Pacific islands with 1385 species, followed by north and south America with about 1,147 species. Globally palms are utilized for various products, including its seed oil, leaves for thatching houses, and cigarette wrappers; the fruits of some palms are edible, and some of them are known for their sap exudates. The medicinal uses of a few palms have been known to the tribal communities in different parts of the world. Coconut palm (Cocos nucifera), sugar palm (Arenga pinnata), nipa palm (Nypa fruticans), kitul palm (Caryota urens), palmyra palm (Borassus flabellifer), date palm (Phoenix dactylifera), wild date palm (Phoenix sylvestris) oil palm (Elaeis guineensis) and raffia palms (Raphia spp.) reported being the sugar-yielding palms in Asia and Africa (Dalibard,1999) [3]. Genus Arenga includes several palm species native to Southeast Asia, southern China, New Guinea, and northern Australia. [4,5]. The palms range from small to medium in size, growing to $2-20 \mathrm{~m}$ tall, with pinnate leaves $2-12 \mathrm{~m}$ long [6].

The Genus includes 24 species- Arenga australasica, A. brevipes, A.caudata, A. distincta, A.engleri, A.hastata, A. hookeriana, A. listeri, A. longicarpa, A.longipes, A. micrantha, A. microcarpa, A. mindorensis, A. obtusifolia, A. pinnata, A. plicata, A. porphyrocarpa A.retroflorescens, A. ryukyuensis, A. talamauen, A. tremula, A. undulatifolia, A.westerhoutii and A.wightii. Most of the plants in the Genus are utilized locally, especially by only some tribal communities and are an integral part of their traditional medicinal system. The potential of these palm is yet to be explored mainly regarding their sugar production and other valuable medicinal properties.

Table 1 shows the available data regarding the distribution and uses of twenty species of the genus

\section{ARENGAS IN INDIA}

The Indian subcontinent is endowed with a rich diversity of flora and fauna, which has enriched the country's biodiversity and has been a vital part of the cultural traditions that exist in the country. Arenga pinnata, A.obtusifolia, A. micrantha, and A.wightii are four members of the Genus Arenga reported in the country.

\section{ARENGA PINNATA -THE MOST VERSATILE PALM SPECIES}

\section{Ecology}

Arenga pinnata is the common sugar palm native to the tropical rain and dry forest of southeast Asia. In India, the palm is

Copyright: (C) The authors. This article is open access and licensed under the terms of the Creative Commons Attribution License (http://creativecommons.org/licenses/by/4.0/) which permits unrestricted, use, distribution and reproduction in any medium, or format for any purpose, even commercially provided the work is properly cited. Attribution — You must give appropriate credit, provide a link to the license, and indicate if changes were made. 
distributed in the northeastern hilly areas of the primary rain forest, especially in Assam, and prefers an altitude up to $400 \mathrm{~m}$. The solitary palm grows up to a height of 10-12 $\mathrm{m}$ with an average flowering period of 5-6 years. Due to the palm's dense root system, it is seen well established in the steep slopes of the hilly areas and has a natural soil stabilizing role. Seeds of the palm are recalcitrant and survive hardly up to $2-3$ months in the soil.

Table 1: Shows the available data regarding the distribution and uses of twenty species of the genus

\begin{tabular}{|c|c|c|c|c|c|}
\hline No. & Plant & Distibution & Habitat & Uses & Reference \\
\hline 1. & $\begin{array}{l}\text { Arenga } \\
\text { westerhoutii }\end{array}$ & $\begin{array}{l}\text { East Asia - southern China, } \\
\text { India, Myanmar, Thailand, } \\
\text { Cambodia, Laos, Vietnam, } \\
\text { Malaysia }\end{array}$ & $\begin{array}{l}\text { Primary rainforest, very } \\
\text { rarely in secondary growth } \\
\text { areas, at elevations up to } \\
1,400 \text { meters }\end{array}$ & $\begin{array}{l}\text { Ornamental value. } \\
\text { Fruit used criminally. } \\
\text { Leaves are used for thatching and wickerworks. } \\
\text { The wood - to make small utensils, or is even used } \\
\text { in construction. } \\
\text { Sugar is derived from the juice by tapping the } \\
\text { peduncle and rachis of the male inflorescence. } \\
\text { The seeds serve as a good source of proteins } \backslash \text { and } \\
\text { crude fiber } \\
\text { Low sugar palm seed jam was developed in } \\
\text { Thailand }\end{array}$ & {$[7]$} \\
\hline 2. & Arenga undulatifolia & $\begin{array}{l}\text { Southeast Asia - Malaysia, } \\
\text { Indonesia, Philippines }\end{array}$ & $\begin{array}{l}\text { Primary rainforest, rarely } \\
\text { in secondary growth areas, } \\
\text { at elevations up to } 1,500 \\
\text { meters }\end{array}$ & $\begin{array}{l}\text { Fruit used criminally } \\
\text { Ornamental value }\end{array}$ & [8] \\
\hline 3. & Arenga tremula & $\begin{array}{l}\text { Southeast Asia - southern } \\
\text { China, Philippines }\end{array}$ & $\begin{array}{l}\text { Lowland areas, especially } \\
\text { in primary rainforest, only } \\
\text { rarely in secondary growth } \\
\text { areas }\end{array}$ & $\begin{array}{l}\text { Fruit used criminally } \\
\text { The leaves - for thatching and wickerwork } \\
\text { The petioles and midribs are used to make } \\
\text { baskets } \\
\text { The stems are a source of starch }\end{array}$ & [9] \\
\hline 4. & Arenga talamauensis & Endemic to Sumatra & primary dipterocarp forest & Not reported & {$[10]$} \\
\hline 5. & Arenga ryukyuensis & Japan, Ryukyu Islands & $\begin{array}{l}\text { Lowland forest or secondary } \\
\text { forest along river margins, } \\
\text { or scrub forest especially } \\
\text { near the seashore }\end{array}$ & Ornamental value & {$[6,11]$} \\
\hline 6. & Arenga retroflorescens & Borneo, Sabah & $\begin{array}{l}\text { Lowland rainforest behind } \\
\text { mangroves }\end{array}$ & Not reported & {$[12]$} \\
\hline 7. & Arenga porphyrocarpa & Sumatra, Java & Rainforests & $\begin{array}{l}\text { root decoction and the palm heart are taken to } \\
\text { treat urinary troubles }\end{array}$ & [13] \\
\hline 8. & Arenga plicata & Sumatra & mixed dipterocarp forest & Not reported & {$[10]$} \\
\hline 9. & Arenga mindorensis & native to Philippines & lowland rainforest & Not reported & {$[10]$} \\
\hline 10. & Arenga microcarpa & $\begin{array}{l}\text { Indonesia to New Guinea } \\
\text { and northern Australia }\end{array}$ & $\begin{array}{l}\text { Primary rainforest, seldome } \\
\text { in secondary growth areas, } \\
\text { at elevations up to } 700 \\
\text { metres }\end{array}$ & $\begin{array}{l}\text { Sagu was made from the trunks by the native } \\
\text { inhabitants. }\end{array}$ & [14] \\
\hline 11. & Arenga longipes & Sumatera & mixed dipterocarp forest & Not reported & [10] \\
\hline 12. & Arenga longicarpa & $\begin{array}{l}\text { Endemic to the southern } \\
\text { part } \\
\text { of Guangdong province }\end{array}$ & $\begin{array}{l}\text { below } 700 \text { m elevation in } \\
\text { Heweishan Natural Forest }\end{array}$ & unknown & [13] \\
\hline 13. & Arenga listeri & $\begin{array}{l}\text { Endemic to Christmas } \\
\text { Island }\end{array}$ & Evergreen forest & unknown & {$[15]$} \\
\hline 14. & Arenga hookeriana & $\begin{array}{l}\text { Thailand Peninsula, North } \\
\text { Malaysia Peninsula }\end{array}$ & Rainforest & suitable for indoor and outdoor decoration & [15] \\
\hline 15. & Arenga hastata & Malaya and Borneo & Open forest & ornamental & [14] \\
\hline 16. & Arenga engleri & $\begin{array}{l}\text { native to islands south of } \\
\text { Japan, including Taiwan } \\
\text { (Formosa) and the Ryukyu } \\
\text { Islands }\end{array}$ & slopes in dense forests & unknown & {$[16]$} \\
\hline 17. & Arenga distincta & Borneo & $\begin{array}{l}\text { Low land mixed dipterocarp } \\
\text { forest }\end{array}$ & unknown & {$[10]$} \\
\hline 18. & Arenga caudata & $\begin{array}{l}\text { Cambodia, Hainan, Laos, } \\
\text { Malaya, South Myanmar, } \\
\text { Thailand, and Vietnam }\end{array}$ & $\begin{array}{l}\text { Lowland rain forests or } \\
\text { deciduous forests }\end{array}$ & unknown & {$[14]$} \\
\hline 19. & Arenga brevipes & Borneo and Sumatera. & Rainforests & $\begin{array}{l}\text { Leaves - cooked } \\
\text { The leaves are mainly used for thatching and } \\
\text { wickerwork }\end{array}$ & [14] \\
\hline 20. & Arenga australasica & $\begin{array}{l}\text { North Queensland } \\
\text { the eastern coast of Arnhem } \\
\text { Land }\end{array}$ & Near sea level to $250 \mathrm{~m}$ & unknown & {$[17]$} \\
\hline
\end{tabular}




\section{Utilization}

A. pinnata is popularly known as sugar palm due to the presence and extraction of palm sugar obtained from the juice tapped from inflorescence stalks and widely used in all kinds of dishes, sweets, drinks, and preserves. It is also fermented to make vinegar or palm wine. Starch extracted from the mature trunk's pith, palm heart, and endosperm of immature seeds boiled with sugar are other food products obtained from the palm [18].Apart from the palm sap, other significant products that can be produced from sugar palm include palm neera, fresh juices, traditional sugar blocks, toddy, crystal and brown sugar, vinegar bio-ethanol starch from trunk, seawater resistant fiber, edible heart fruits, leaves for roofing, brooms, matting, baskets, cigarette papers, cattle feeds and its starch inside the stem can be processed to make biopolymer [19]-[23]. The palm's importance was enhanced mainly due to the production of bioethanol from the palm sugar by the process of fermentation using yeast. Bioethanol has now been used as a renewable energy source like the compound obtained from other fuel yielding plants. The sugar palm can yield the highest productivity of bio-ethanol (20,160 1/ha/year) compared to other sources such as cassava (45001/ha/year), sugarcane (5025 1/ha/year), sago (4133 1/ha/year), and sweet sorghum (6000 l/ha/ year) [24].It was a remarkable achievement of Renewable Energy Lab University of Sam Ratulangi Manado that the bioethanol production with a purity of 99 percentage was successfully obtained by manipulating the column temperature of the reflux distillation apparatus [25]. The large-scale commercialization of sugar palm plantations of about 4,000,000 ha is in the process of development, especially in Indonesia, to utilize this tremendous potential of sugar palm plants.

Apart from being the source of a renewable energy source, the sugar palm is also known for its fiber, which shows high durability and resistance to saltwater damage. The natural woven fiber is wrapped around the tree from the bottom to the tree's upper part. The major composite of the palm fiber in the order of their concentration present in the fiber was found to be hollow cellulose fibers, cellulose, ash, lignin, and hemicelluloses. The highest constituent hollow cellulose had a value of $65.55 \%$ followed by cellulose with a value of $56.55 \%$ in the palm fiber [26]. The palm fiber was found to be heat resistant up to $150^{\circ} \mathrm{C}$ with a flash point at around $200^{\circ} \mathrm{C}$ [27]. The palm sugar is also used as a potential raw material for the preparation of biopolymers, biodegradable glycerol is used as plasticizer. It was reported that the physical properties such as density, moisture content, water absorption and thickness swelling of the plasticized sugar palm starch was lower with the increase of glycerol [28]. Poeloengasih (2011) in his studies used the palm starch and combined with chitosan to produce edible film materials. Plasticizer such as glycerol and sorbitol were added to produce strong and flexible film. The composite films were prepared from chitosan and sugar palm starch in various ratios with glycerol and sorbitol [29].

\section{Conservation Strategies}

Both in vitro and in vivo seed germination studies of A.pinnata have revealed that the seeds have a dormancy of 1-12 months.
The main factor which contributes to dormancy was found to be the impermeable seed coat with inhibitory substances. Isolated embryo germinated in vitro much rapidly as compared to the whole seed. Seed scarification was succeeded in increasing the germination percentage [30]. Considering the wide range in which the palm is utilized, and it can be said as a potential candidate for future research which will further make it popular in the commercial sector.

\section{ARENGA OBTUSIFOLIA}

\section{Ecology}

The palm A. obtusifolia is mainly distributed Arunachal Pradesh which lies in the Eastern Himalayas and in the boarders of Assam. The state Arunachal Pradesh is endowed with about $30 \%$ flora of Indian subcontinent and is biodiversity hotspot [31]. The biennial state forest report 2011 shows that the state has more than $80.5 \%$ of its total geographical area $(83,743 \mathrm{sq} \mathrm{km}$.) under forest [32]. The palm prefers subtropical climates with plenty of rainfall, high humidity, well-drained soil and also, they tolerate high light intensity. They are mainly confined to the sloping hilly terrains of the mountains especially adjacent to streams. Fully mature trees attain a height of about $3.5 \mathrm{~m}$ and have a trunk circumference of $30-60 \mathrm{~cm}$. The palm seeds germinate after one month at 28-32 ${ }^{\circ} \mathrm{C}$.

\section{Utilization}

The field study conducted by Ranjay K. Singh (2015) from Central Agricultural University, Pasighat reveals several important aspects regarding the usage and conservational strategies of this palm adopted by the Adi community of Arunachal Pradesh [33]. The Adi community comprises of 10 major ethnic sub-groups and they mainly reside in the subtropical and sub temperate regions of the state. The Adi men are engaged in ploughing, digging and other physical activities for jhum agriculture and women are involved in activities like crop management, collecting firewood and other ethnobotanical products from the forest. The tree is popularly known as tasat among the Adi tribal community of Arunachal Pradesh. The peel, leaf and stem bark of the palm tree are harvested when it attains a maturity of about $4-5$ years. The tree yields fruits after 8-9 years with two crops per year. The economic life of the tree is 14-15 years. The flowering starts in June and can extend up to July followed by fruiting. The fruits ripen by the end of September and the second fruiting starts in October and the ripe fruits are harvested in next January.

The stem pith of the palm is been used by them as food during drought and for the preparation of various ethnic beverages. The ethnic beverage prepared by chopping the palm is known by the name apong among the Adi community and is considered as precious cultural food. The bread prepared from the chopped stem is called by name etting among the community and is a rich source of carbohydrates during drought and food crisis. Apart from using the palm as a source of food the Adi community depends on the palm 
leaves for healing wounded cattle and pigs. The chopped stem pith is boiled and given to pigs. The palm leaves are used by the Adi livestock owners for rearing mithun, pigs and cows as well as for making broomsticks, ropes and for thatching their houses [33].

\section{Conservation Strategies}

The socio-cultural significance of this endangered and native palm among the Adi community has led them to the establishment of plantations around their settlements. Women of the tribal communities together with many informal indigenous institutions played an important role in development and conservation of the palm plantations around their village settlements. Kebang and Reglep are two widely known indigenous institutions of men and women, respectively which are involved in the sustainable management and conservation of the palm plantations.

The Reglep usually consist of elder women who supervise harvesting and monitor the age and number of trees to be harvested. The magnitude of the harvest depends on the individual need of each households and the surplus harvest is mutually shared among the members.

The Kebang consist of people who take decisions to resolve disputes between the members of the community. They function like the court which hears the disputes regarding the unauthorized harvest and overexploitation of the endemic palm species. They have the power to give punishments if the accused is proved guilty.

Overall both these tribal indigenous institutions play an effective and valuable role in ensuring the sustainable use of palm and thereby conserving it for the future generation. The advent of many commercial crops has led to the reduction in the dependency of the community people for this valuable palm resource. This has led to the loss of traditional knowledge regarding the utilization and conservation of the palm. Promoting the women and the traditional institutions involved in conservation to develop strategies for transferring the traditional knowledge to future generations with the help government departments can help in sustaining the utilization and there by conservation of this endangered and endemic palm of our country. [33]

\section{ARENGA WIGHTI}

\section{Ecology}

The palm is endemic to Southern Western Ghats in Kerala and it is known as 'Kattuteng [34]. It is confined to the evergreen forests at altitudes ranging from 300 to $1000 \mathrm{~m}$. The shade loving palm grows up to a height of $10 \mathrm{~m}$ and diameter of $30 \mathrm{~cm}$ and is usually seen in valleys with suitable for its colony formation [35]. Although the palm is reported in several districts, two major colonies can be seen in Thiruvananthapuram and Idukki districts.

\section{Utilization}

Local tribal communities like Mudhuvans of Idukki depend on the palm mainly for its starch from the pith and toddy which is collected by tapping its inflorescence [36]. The inflorescence of the palm is used for religious ceremonies and the leaves which resemble coconut leaves are used for thatching the huts and pandals in their settlement. Although the fruit contains irritant needle like oxalate crystals, it is dehusked and boiled repeatedly for making it suitable for consumption. The dried kernels are powdered and are mixed with rice flour for the preparation of several food items. The terminal bud also called cabbage of the palm is edible, but nowadays it is seldom used by them.

Starch is collected from the palm stem of an age of $15-20$ years by felling off the tree and removing its sclerenchymatous hypodermis. The cylindrical cortex is chopped, and the starch is extracted in water which is further dried and used as food supplement as well as for the preparation of other indigenous food items like kurukk and upuma

The palm is tapped from the unopened spadix and the toddy is collected in a long bamboo from the month of April and is consumed as wine without fermenting. The fresh toddy is also given to patients suffering from jaundice [37]. Vinegar and jaggery are the two value added products derived from the palm wine [38]. The Malampandaram tribes of Achancovil forest range in the Kollam District of Kerala use the white powdery material from the leaf of the palm for wound healing [39].

The plant has gained attention among scientific community due to its medicinal value reported in various scientific literatures. HPLC and GC-MS analysis of the methanolic extract of the leaves and fruit has confirmed the presence of various antimicrobial and antioxidant phytochemicals like gallic acid, ascorbic acid, chlorogenic acid and caffeine. The antimicrobial activity of the leaf and fruit extracts seems to very pronounced against Staphylococcus aureus which is the most common infectious skin pathogen of humans [40]. The ethanolic extract of the stem pith was administered in various doses in carrageen induced paw oedema in Wistar rats to study the anti-inflammatory potency.

Dosage depended inhibition of oedema was observed which was comparable to the standard drug indomethacin. Similarly, the analgesic activity of the ethanol stem pith extract was evaluated in Swiss albino mice using acetyl salicylic acid as standard. The results were comparable to the standard in a dosage dependent manner [40].

From the available scientific literature it is evident that A.wightii is potential palm which can be utilized commercially for harvesting its toddy and for products which has great medicinal value.

Promoting the non-destructive utilization of the palm among the tribes along with its conservation should be the first step which will lead to the sustainable utilization of this endemic palm species. More scientific studies to validate the medicinal 
value of the palm derived products should be done which can confirm it as a promising source of raw material for the pharmaceutical industry.

\section{Conservation Strategies}

Currently there no efficient conservation strategies implemented for A. wightii. Deep insight into the seed physiology of the palm is needed for designing efficient strategies for conservation. Ideal conditions for its seed germination should be elucidated scientifically which can help its propagation and establishment in a large scale. Conservation strategies as in A. obustifola of the northeast can be implemented for A. wightii with the involvement of tribal communities which can promote the sustainable usage of this valuable palm among them. Moreover, seed physiological studies can contribute to the effective establishment of large-scale plantations of the palm for commercial purpose.

\section{ARENGA MICRANTHA}

\section{Ecology}

The palm is commonly known as Tibetan sugar palm distributed in the cloud forest of Tibet, Bhutan and in North East India. It is a dioecious, hepaxanthic solitary palm that attains a maximum height of $2 \mathrm{~m}$ which is observed in subtropical or tropical moist lowland forests with an altitude range from 1400-2150 m [41]. Flowering is reported to be very rare and requires pollination for fruiting. It is said to be the hardest species in the Genus Arenga and currently is in the endangered category. The altitude specificity of the plant proves that it is an ideal species of the Genus which can be said as cold-tolerant.

\section{Utilization}

This non-woody palm is known locally as Ingkuri in the forest regions of Papuan islands and is considered as a potential source of forest products. The shoot extracts and fruits are used for preparation of beverages [42]. The leaves are used as roadside shelters in some parts of Sikkim and its borders.

\section{Conservation Strategies}

Conservation studies are yet to be done in this species in northeastern parts of India following the strategies adopted for Arenga obustifolia by the local and government bodies for promoting conservation and sustainable utilization.

\section{Seed biology of Arengas}

Almost all the seeds of most of the species in this Genus is characterized by the presence of a hard, impermeable seed coat [43]. Impermeability of the seed coat is the result of thickness of testa [44-46]. Seed germination in Arenga australasica is remote-non ligular type. It is a type of germination in which the cotyledonary petiole elongates, radicle and plumule emerges from the cotyledonary sheath [47]. From the germination studies of A. australasica it is evident that the untreated seeds showed low germination rates when compared with scarified or heat-treated seeds [17]. Secondary dormancy is a phenomena observed in their seeds which refers to the ability of the seeds to remain dormant in unfavorable conditions, germinate and establish when conditions are favorable for its establishment [48-51].

Seed germination studies in Arenga. westerhoutii reveals that 36 months old seeds with both ends cut has the highest efficiency of germination as compared to hot water treated seeds. Hot water treatment seems to harm the palm embryos which reduced the germination percentage. Single leaf together with two third of leaf cutting was the most ideal stage for uprooting and transplantation of their seedlings for large scale plantation establishment [7].

Seed germination in untreated Arenga pinnata was reported to be $27 \%$ [52]. Dormancy of the seeds was successfully broken by scarification treatments after 30-365 days [53]. In another study with different concentration of gibberellic acid on seeds of A. pinnata, $170 \mathrm{ppm}$ of $\mathrm{GA}_{3}$ showed as maximum germination rate of $83 \%$ as compared to untreated samples. Parameters like length of plumule, length of root and plant length were measured to be high in 170ppm GA treated seeds. Similarly, the effect of different concentrations of $\mathrm{HCl}, \mathrm{HNO}_{3}$ and $\mathrm{H}_{2} \mathrm{SO}_{4}$ were studied, treatment with $0.4 \%$ of $\mathrm{HCl}$ resulted in $100 \%$ germination. [54]. Another study on scarification of A.pinnata seeds revealed that scarification in the embryo part resulted in best germination percentage at around 99.81\% [55]. These finding may help the farmers to synchronize germination and growth of A.pinnata seeds for plantation establishments of this multiutility palm. Few studies in other Arenga reported that A. obtusifolia, A. engleri, A. pinnata, A. tremula, A. microcarpa, A. undulatifolia and A. wightii broke dormancy after 83-126 days without any treatments [52]. Germination studies in the seeds of A.wightii indicated that their low initial germination percentage. Seed setting problems in this medicinal palm has also contributed to its local endemism and vulnerable status

\section{CONCLUSION}

The members of the Genus Arenga are mostly highly ornamental as well as are dependable candidates for its products. The local communities which are already involved in harvesting various products from these palms must be encouraged in conserving the palms through their traditional communal strategies. The local government must take active measures in large scale planting of these palm species thereby promoting the traditional tapping workers. Phytochemical studies will lead to the scientific evaluation of the palm products and a hike in its pharmacological value. The development of value-added products from the palm wine can enhance its economic value and can raise the income of the workers involved in the palm establishment and harvesting. Seed physiological studies in these endemic palm species will lead to the discovery of the ideal conditions for large scale seedling establishment which in turn lead to conservation of these valuable palms. 


\section{REFERENCES}

1. Couvreur T L, Kissling W D, Condamine F L, Svenning J C, Rowe N P, Baker W J. Global diversification of a tropical plant growth form: environmental correlates and historical contingencies in climbing palms. Frontiers in genetics. 2015: 5; 452.

2. Johnson D. Palm utilization and management in Asia: examples for the neotropics. Bulletin Institut Etudes Andines. 1992;21:727-40.

3. Dalibard C. Overall view on the tradition of tapping palm trees and prospects for animal production. Livestock research for rural development. 1999;11(1):1-37.

4. Petoe P, Cámara-Leret R, Baker WJ. A monograph of the Hydriastele wendlandiana group (Arecaceae: Hydriastele). Kew Bulletin. 2018;73(1):17.

5. Wendl and Drude. Guanglangshu, Arenga Labillardière Flora of China Vol 23 Bull. Sci. Soc. Philom. Paris. 1800;2: (162).151.

6. Henderson A Palms of Southern Asia: Princeton University press, Princeton and Oxford 2009; 1-197.

7. Chantaraboon A, Burikam I, Pampasit S, Pongsattayapipat R. Improvement of Sexual Propagation in Sugar Palm (Tao)(Arenga westerhoutii Griff.) Seeds. Thai Journal of Agricultural Science. 2009;42(3):67-70.

8. Yang X, Barton HJ, Wan Z, Li Q, Ma Z, Li M, Zhang D, Wei J. Sagotype palms were an important plant food prior to rice in southern subtropical China. PloS one. 2013;8(5).

9. Hayasak D, Fujiwara K. Habitat differences and spatial distribution patterns of maritime strand forest and adjacent inland forest on subtropical Iriomote Island, Southern Japan. Ecotropica. 2007;13: 121-134.

10. Mogea J P. Four new species of Arenga (Palmae) from Indonesia. Reinwardtia, 2003; 12(2):181-189.

11. Henderson A J. ANew Species of Arenga (Palmae). Taiwania.2006;51(4) 298-301

12. Dransfield J. Notes on the palm flora of central Sumatra. Reinwardtia. 2014;8(4), :519-531

13. Jeanson ML, Lixiu G. Arenga longicarpa, a Poorly Known Species from South China. Palms. 2011; 55(3).

14. Dransfield J, Mogea J P. The flowering behaviour of Arenga (Palmae: Caryotoideae). Botanical journal of the Linnean Society. 1984; 88(1-2): 1-10.

15. Tidemann C R, Yorkston H D, Russack A J The diet of cats, Felis catus, on Christmas Island, Indian Ocean. Wildlife Research.1994; 21(3): 279-285

16. Liang Y, Yang S. Seed dormancy mechanism and ways to accelerate germination of Syagrus romanzoffiana and Arenga engleri. Subtropical Plant Science. 2005; 34(4): 20-24.

17. Latifah D, Congdon R A, Holtum J A. A Physiological Approach to Conservation of Four Palm Species: Arenga australasica, Calamus australis, Hydri-Astele wendlandiana and Licuala ramsayi. Reinwardtia.2014; 14(1):237-247.

18. De Padua, I., Bunyapraphasara S, Lemmens N. Medical and potsonous Plan I. Plant Resources of South-East Asia. 2003; 12.1:89-96

19. Ishak M R, Sapuan S M, Leman Z, Rahman M Z. A, Anwar U M K, Siregar J P. Sugar palm (Arenga pinnata): Its fibres, polymers and composites. Carbohydrate polymers. 2013; 91(2),:699-710.

20. Redhead, J. F. (1989). Utilization of Tropical Foods: Tropical OilSeeds (Vol. 5). Food \& Agriculture Org.

21. Lay A . Rekayasa teknologi alat pengolahan bioetanol dari nira aren. Bulletin Palma. 2009:37:100-114.

22. Johnson D. Palms as Multipurpose Cash and Subsistance Tree Crops. In Proceedings of an international workshop held in Pataya, Thailand; 1987

23. Sath K, Borin K, Preston T R. Survey on feed utilization for cattle production in Takeo province. Livestock Research for Rural Development, 20(Suppl.); 2008.

24. Allorerung D. Aren tanaman serbaguna. In: Workshop Budidaya dan Pemanfaatan Aren untuk Bahan Pangan dan Energi ;2007

25. Sangian F, Tongkukut S.Study of Bio-Ethanol Preparation from Arenga Palm Sugar. Jurnal IImiah Sains. 2011; 11(2): 259-267.

26. Ishak M R, Sapuan S M, Leman Z, Sahari J Ibrahim M S. Chemical composition of sugar palm (Arenga pinnata) fibres: The effects of natural degradation. In Proceedings of the international conference on design and concurrent engineering Malacca, Malaysia; 2010

27. Siregar J P. Tensile and flexural properties of Arenga Pinnata filament (ljuk Filament) reinforced epoxy composites. MS thesis. Universiti Putra Malaysia;2005

28. Sahari J, Sapuan SM, Zainudin ES, Maleque MA. A new approach to use Arenga pinnata as sustainable biopolymer: Effects of plasticizers on physical properties. Procedia Chemistry. 2012; 4:254-9.

29. Poeloengasih C D, Zahra, H A, Widyasari S (2011). Preparation and characterization of film made from chitosan and Arenga (Arenga pinnata) starch. International workshop on Innovation in Polymer Science and Technology Proceedings;2011

30. Asikin D. Puspitaningtyas DM. Study on in vitro and in vivo seed germination of Arenga pinnata (Wurmb) Merr. In: Seminar Hasil Penelitian dan Pengembangan Bioteknologi, Cibinong, Bogor (Indonesia), Puslitbang Bioteknologi.;2000

31. Government of Arunachal Pradesh. Report on Arunachal Pradesh Bio-diversity. Itanagar: Environment and Forest Department; 2002

32. The Telegraph "Arunachal Aims to Increase Green Cover". The Telegraph, Calcutta, India, January. Available from http://www. telegraphindia.com/1130117/jsp/northeast/story_16449087.jsp\#. Uk18 UBCSFIF.[Last accessed on 2020 May 20]

33. Singh R K, Srivastava R C, Pandey C B, Singh A. Tribal institutions and conservation of the bioculturally valuable 'tasat' (Arenga obtusifolia) tree in the eastern Himalaya. Journal of Environmental Planning and Management. 2015; 58.1:69-90.

34. Manithottam J, Francis M S. Arenga wightii Griff.-A unique source of starch and beverage for Muthuvan tribe of Idukki district, Kerala. Indian Journal of Traditional Knowledge. 2007; 6:195-198.

35. Renuka C. Kfri Palmetum. Kfri Research Report No; 2008

36. Asha, V. V., \& Pushpangadan, P. Hepatoprotective plants used by the tribals of wynadu, malappuram and palghat districts of Kerala, India. Ancient science of life. 2002; 22.1: 1-8.

37. Renuka C, Bhat K. V, Basha S C. Palm resources of Kerala and their utilisation. KFRI Research Report ;1996.

38. Mathew J, George K V. Medicinal plants used by malampadaram tribals in achankovil forests of Kerala to cure snake bite, wound and bone fracture. Life Sciences Leaflets. 2013;8: 50-54.

39. Devanesan AA, Aseervatham SB, Raju K, Sivasudha T. Detection of Phenolics and Appraisal of Antioxidant and Antimicrobial Properties of Arenga wightii. International Journal of Pharmaceutical Sciences Review and Research. 2014; 26:55-62.

40. Periya, Shikha, Latha P G , Suja S, Rajasekharan S, Anuja G I. Anti-inflammatory and analgesic activity of Arenga wightii Griff.-an endemic palm of western ghats. International Journal of Pharmacy and Pharmaceutical Sciences. 2015: 7:203-207.

41. Noltie $\mathrm{H} J$.Arenga micrantha: a little-known eastern Himalayan palm. Palms. 2000:44.1: 14-18

42. Cabuy R. L, Marwa J, Manusawai J, Rahawarin Y Y. Non-woody plant species of Papuan Island forests, a sustainable source of food for the local communities; 2012

43. Uhl W. Dransfield J .Genera palmarum: a classification of palms based on the work of Harold E. Moore, Jr. First edition. Allen Press, Lawrence; 1987

44. Dessai G, Salunkhe J. Seeds handook. Marcell Dekker Inc., New York; 1997

45. Bass L N. Physiological and other aspects of seed preservation. In: Rubenstein, I. (Ed). The plant seed: development, preservation and germination. Academic Press, New York; 1979

46. Tran V N, Cavanagh A K.Structural aspect of dormancy. In: Murray, D. R. (Ed.).Seed physiology: germination and reserve mobilization. Academic Press, Sydney; ( 1984

47. Kasana R C, Sharma U K, Sharma N, Sinha A K. Isolation and identification of a novel strain of Pseudomonas chlororaphis capable of transforming isoeugenol to vanillin. Current microbiology. 2007:54.6:457-461

48. Latifah D. Ecology of palms (Arecaceae) in response to cyclonic disturbances in North Queensland, Australia. School of Marine and Tropical Biology, James Cook University, Townsville. (PhD Thesis); 2011

49. Baskin C C, Baskin J M .Seeds: ecology, biogeography, and evolution of dormancy and germination. Academic Press, San Diego; 2001.

50. Fenner M. Thompson K . The ecology of seeds. Cambridge University Press, Cambridge; 2005.

51. Vleeshouwers $L M$, Bouwmeester $H J$, Karssen $C M$.Redefining seed dormancy: an attempt to integrate physiology and ecology. Journal of Ecology .1995;83: 1031-1037. 
Pillai, et al

52. Koebernik J .Germination of palm seed. Principes. 1971;15: 134-137.

53. Mujahidin M, Sutrisno S, Latifah D, Handayani T, Fijridiyanto I A. Aren (Arenga pinnata): budidaya dan prospeknya. Lembaga IImu Pengetahuan Indonesia (LIPI)-Pusat Konservasi Tumbuhan Kebun Raya Bogor, Bogor. (In Indonesian); 2003.

54. Noorshilawati Abdul Aziz and Nur Suraya Abdullah. Effect of Plant
Growth Hormones and Chemicals on Germination Rate and Growth of Arenga pinnata Seeds. American-Eurasian J. Agric. \& Environ. Sci. $2016 ; 16.7:$ 1378-1382.

55. Elidar $Y$.Seed emergence and growth of the short age sugar palm (Arenga pinnata) as a response of seed scarification and liquid organic fertilizer application. Asian Journal of Agriculture.2018;2: 8-13. 